\title{
Parkin and Parkinson's Disease
}

\author{
Shiam-Peng Tay' ${ }^{1}$, Grace G.Y. Lim ${ }^{1}$, \\ Calvin W.S. Yeo ${ }^{1}$ and Kah-Leong Lim ${ }^{1,2,3}$ \\ ${ }^{1}$ Department of Physiology, National University of Singapore, \\ ${ }^{2} A * S T A R$ Duke-NUS Neuroscience Research Partnership, \\ ${ }^{3}$ National Neuroscience Institute \\ Singapore
}

\section{Introduction}

Parkinson's disease (PD) is the most common neurodegenerative movement disorder affecting millions of predominantly elderly individuals worldwide. Originally described as "The Shaking Palsy" in 1817 by the British physician, James Parkinson, the disease is attended by a constellation of motoric deficits including bradykinesia (slowness in movements), postural instability, rigidity and tremor that ultimately result in near total immobility. Although pathological changes are distributed in the PD brain, the principal neuropathology that underlies the characteristic motor phenotype of PD patients is unequivocally the loss of midbrain dopaminergic (DA) neurons in the substantia nigra pars compacta (SNpc), which results in a severe depletion of striatal dopamine and thereby an impaired nigrostriatal system that otherwise allows an individual to execute proper, coordinated movements. This specific pattern of neurodegeneration in PD is often accompanied by the presence of eosinophilic intracytoplasmic inclusions known as Lewy bodies (LBs) in surviving neurons in the $\mathrm{SN}$ as well as in other affected brain regions such as the dorsal motor nucleus of the vagus, locus ceruleus (LC) and olfactory nuclei (Braak et al., 2003). In advanced stages of the disease, LB pathology can also be found in the limbic structures and neocortex (Braak et al., 2003). Nonmotor features arising from these extra-nigral neuronal lesions, including autonomic, sensory and cognitive dysfunctions, present additional sources of considerable consternation and disability for affected individuals (Olanow et al., 2008). Thus, although SN pathology is often regarded as the most important hallmark of $\mathrm{PD}$, the disease is increasingly being recognized as a multi-system disorder affecting not only dopaminergic, but also noradrenergic, cholinergic and serotonergic systems (Alexander, 2004).

Despite intensive research, the etiology of PD remains poorly understood and no current treatments can unequivocally slow or stop the degenerative process. Current therapies for $\mathrm{PD}$ are palliative at best and the mainstay is pharmacologic intervention via DA replacement (e.g. through L-DOPA administration). Major drawbacks with current therapies include the inevitable loss of effectiveness and increasing drug-induced side effects as the disease progresses. Invariably, the debilitating nature and morbidity of the disease present significant healthcare, socio-economic and emotional problems. As the world population rapidly ages, these problems undoubtedly would also increase. Notably, a recent study by Dorsey et al projected that the number of PD cases in Europe's five most 
and the world's ten most populous countries would increase to 9 million in year 2030 (Dorsey et al., 2007). This is definitely a worrying trend, and one that aptly emphasizes the urgency to develop more effective treatment modalities for the PD patient.

In large part, the difficulty in identifying disease-modifying drugs for PD is due to: i) our current limited understanding of the molecular mechanism(s) that underlies the pathogenesis of PD (the illumination of which would allow the identification and therapeutic exploitation of key molecules involved in the pathogenic process), and ii) the lack of a truly representative mammalian model of PD that recapitulates accurately the progressive process as well as the nature and distribution of the human pathology. However, during the last decade or so, the identification and functional characterization of several genes whose mutations are causative of rare familial forms of PD have provided tremendous insights into the molecular events underlying neurodegeneration in PD. Alongside, several genetic models of PD have also been generated that replicate the disease phenotype to varying degrees of success. Collectively, these studies implicate aberrant mitochondrial and protein homeostasis as key contributors to the development of PD, with oxidative stress likely acting an important nexus between the two pathogenic events.

\section{Parkin and Parkinson's disease}

Mutations in $\alpha$-synuclein, parkin, DJ-1, PINK1, and LRRK2 are currently recognized to be unequivocally linked to familial parkinsonism (Table 1). Whereas $\alpha$-synuclein and LRRK2 mutations are causative of dominant parkinsonism, mutations in parkin, DJ-1, PINK1 are associated with recessive parkinsonism (Thomas and Beal, 2007).

\begin{tabular}{|c|c|c|c|c|}
\hline Locus & Chromosome & Gene & Inheritance & Function \\
\hline PARK1 \& 4 & $4 q 21-23$ & $\begin{array}{l}\alpha \text {-synuclein } \\
\text { (SNCA) }\end{array}$ & Dominant & $\begin{array}{l}\text { Unclear (presynaptic } \\
\text { protein) }\end{array}$ \\
\hline PARK2 & $6 q 25.2-27$ & Parkin (PRKN) & Recessive & Ubiquitin ligase \\
\hline PARK3 & $2 \mathrm{p} 13$ & Unknown & Dominant & - \\
\hline PARK5 & 4 p14 & UCHL1 & Dominant & Ubiquitin hydrolase \\
\hline PARK6 & $1 \mathrm{p} 35-36$ & PINK1 & Recessive & $\begin{array}{l}\text { Putative } \\
\text { serine/threonine kinase }\end{array}$ \\
\hline PARK7 & $1 p 36$ & DJ-1 & Recessive & Redox sensor \\
\hline PARK8 & 12p11.2-q13.1 & LRRK2/dardarin & Dominant & $\begin{array}{l}\text { Putative } \\
\text { serine/threonine kinase }\end{array}$ \\
\hline PARK9 & $1 p 36$ & ATP13A2 & Recessive & $\begin{array}{l}\text { Lysosomal P-type } \\
\text { ATPase }\end{array}$ \\
\hline PARK10 & 1 p32 & Unknown & Unknown & - \\
\hline PARK11 & $2 q 37.1$ & Unknown & Dominant & - \\
\hline PARK12 & Xq21-q25 & Unknown & Unknown & - \\
\hline PARK13 & $2 \mathrm{p} 12$ & $\mathrm{Omi} / \mathrm{HtrA} 2$ & Dominant & $\begin{array}{l}\text { Mitochondrial serine } \\
\text { protease }\end{array}$ \\
\hline PARK14 & 22q13.1 & PLA2G6 & Recessive & Phosopholipase \\
\hline PARK15 & $22 q 12-q 13$ & FBXO7 & Recessive & $\begin{array}{l}\text { Component of SCF E3 } \\
\text { complex }\end{array}$ \\
\hline PARK16 & $1 q 32$ & Unknown & Unknown & - \\
\hline
\end{tabular}

Table 1. PD-linked genes 
Apart from these, mutations in UCHL1, Omi/HtrA2 and ATP13A2 have also been suggested to cause parkinsonism, but their relevance to PD is currently unclear because the purported disease-causing mutation is either extremely rare in occurrence (e.g. UCHL1 I93M) (Healy et al., 2004) or present in control population at similar frequencies (e.g. Omi/HtrA2 G399S) (Simon-Sanchez and Singleton, 2008) or otherwise results in a clinical phenotype that is rather divergent from classical PD (e.g. ATP13A2-linked parkinsonism that is characterized by mild parkinsonism and prominent cognitive defects) (Ramirez et al., 2006). More recently, two other genes, PLA2G6 encoding a phospholipase and FBXO7 encoding a component of the Skp-Cullin-Fbox (SCF) ubiquitin ligase complex, have also been identified to be associated with recessive parkinsonism (Di Fonzo et al., 2009; Paisan-Ruiz et al., 2009). The function of these various disease-associated genes, especially the unequivocal ones, has been extensively characterized. Interestingly, it turned out that these seemingly functionally disparate PD-linked proteins that have no clear relationship with each other at first glance may all influence either protein or mitochondrial homeostasis, with some, like parkin, being directly involved in both. Accordingly, in the absence of functional parkin, aberrations in both protein and mitochondrial quality control (QC) would ensue that may eventually trigger the demise of susceptible neurons. Indeed, the pivotal role parkin plays in maintaining DA neuronal survival is underscored by our current recognition that parkin dysfunction represents not only a predominant cause of familial parkinsonism but also a formal risk factor for the more common, sporadic form of PD. Here, we shall discuss the role of parkin in PD and why a better understanding of parkin function can help elucidate potential therapeutic strategies for the disease.

\subsection{Parkin mutations and parkinsonism}

Mutations in parkin were originally identified in Japan more than a decade ago to be causative of autosomal recessive juvenile parkinsonism (ARJP) (Kitada et al., 1998). Following this discovery, several ethnically diverse individuals with early-onset PD (age $<45$ years) in other parts of the world were also found to carry parkin mutations, which occur at a frequency of about $10-20 \%$ and $50 \%$ in sporadic and familial early-onset cases respectively (Lucking et al., 2000; Mata et al., 2004; Periquet et al., 2003). Clinically, parkin-associated parkinsonism is often quite indistinguishable from idiopathic PD, with bradykinesia, rigidity and rest tremor being variably combined in both disorders. However, parkin-related patients tend to exhibit slower disease progression and better response to L-DOPA (and also a higher tendency to develop L-DOPA-induced dyskinesia) than those with parkinsonism of different etiologies. Additionally, other less typical features common to parkin cases include prominent dystonia, presence of hyperreflexia and more symmetrical presentation of symptoms, although none of these features are sufficiently specific to be diagnostic of parkin mutations. Limited post-mortem studies of known parkin cases conducted to date demonstrated neuronal loss predominantly in the $\mathrm{SN}$ and LC regions of the brain that is accompanied by gliosis. Importantly, the majority of parkin-related cases are devoid of classic LBs (Hayashi et al., 2000; Mori et al., 1998; Pramstaller et al., 2005), suggesting that parkin-associated parkinsonism is pathologically distinct from idiopathic PD, and as such may represent a phenocopy of the latter. However, this is debatable as LBs are found in at least two cases of parkin-related PD (Farrer et al., 2001; Pramstaller et al., 2005). An attractive corollary to this is that functional parkin may facilitate LB formation, which we favor as a working hypothesis (see section 2.2). 
Structurally, the 465 amino acid-containing human parkin protein is comprised of a ubiquitin-like (UBL) domain at its N-terminus, a RING1-IBR-RING2 domain at its Cterminus and a unique middle segment that links the two domains (Fig. 1). Similar to other RING finger-containing proteins, parkin functions as an E3 ubiquitin ligase associated with the ubiquitin-proteasome system (UPS). To date, more than 100 different parkin mutations have been described with over 50 of these being missense/nonsense substitutions (Fig. 1). Although most of the missense mutations occur within the RING1-IBR-RING2 catalytic moiety, many of them are also found along the length of the protein outside this region. Further, exonic mutations are also frequently observed with deletion of exon 3 and/or 4 being the most common (Hedrich et al., 2004).

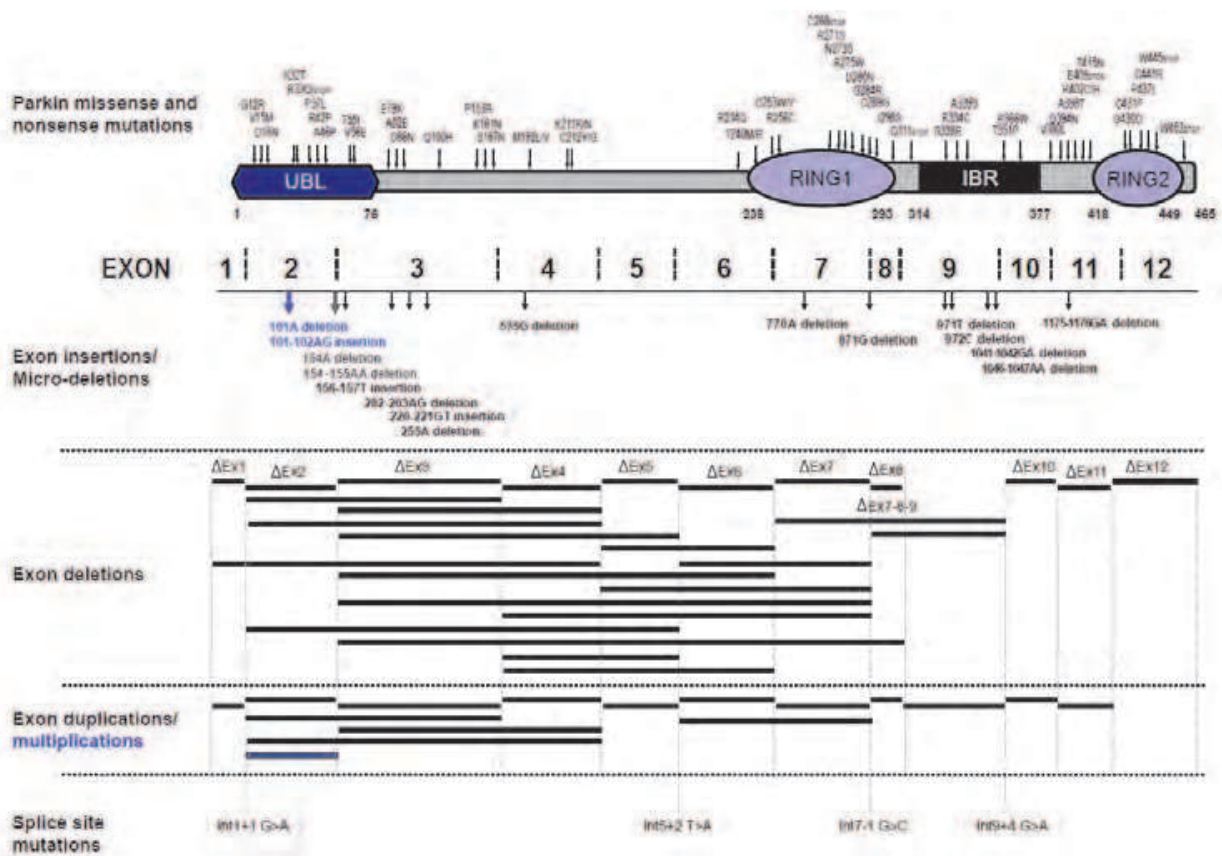

Fig. 1. Schematic depiction of parkin structure and associated disease-linked mutations including missense/nonsense substitutions, insertions, microdeletion as well as exonic multiplications and deletions.

Curiously, despite the heterogeneity, there is no discernable difference in the clinical manifestations among PD patients carrying different parkin mutations. This suggests that substitutions of amino acids resulting from missense mutations are as detrimental to parkin function as are truncation and deletion mutations. Another curious, albeit controversial feature of parkin-related cases is that a single allelic hit might be sufficient to cause disease, which contradicts the widely accepted notion that parkin mutations transmit in a classical autosomal recessive manner (Klein et al., 2007). Supporting this, Hilker and colleagues demonstrated via positron emission tomography that asymptomatic carriers of a single parkin mutation exhibit significantly reduced fluorodopa uptake in the striatal regions compared to control subjects, suggesting preclinical dopaminergic dysfunction (Hilker et al., 
2001). In concordance with this, a subsequent transcranial sonography-based study revealed SN hyperechogenicity in 5 out of 7 asymptomatic carriers of parkin mutations (Walter et al., 2004). Moreover, fMRI analysis of heterozygous parkin carriers demonstrated reorganization of striatocortical motor loops that possibly reflect a compensatory effort to overcome latent nigrostriatal dysfunction (Buhmann et al., 2005). Notwithstanding these evidences, the pathogenicity of single heterozygous parkin mutation is a subject of ongoing debate. An outstanding issue is whether heterozygous parkin mutations may have arisen incidentally. Several studies have sought to address this, but the findings have thus far been inconsistent, i.e. heterozygosity for parkin mutations was reported to be similar between patients and controls in some studies (Kay et al., 2007; Lincoln et al., 2003) but also found to be unique to PD cases in others (Clark et al., 2006b). Another issue is how mutations occurring on a recessive gene can contribute to disease pathogenesis. Given the neuroprotective role of parkin function (discussed in later section), one could envisage that parkin haploinsufficiency could increase the risk of heterozygous parkin mutation carriers for PD. Supporting this, a promoter variant of parkin associated with a lower expression of parkin was found to occur more commonly in PD cases than in controls (West et al., 2002). Alternatively, emerging evidence suggest that certain parkin mutations may also contribute to neurotoxicity directly. The role of single heterozygous parkin mutations thus remains unresolved.

Notwithstanding the controversy surrounding the role of heterozygous parkin mutations, how parkin mutations disrupt the function of the protein was a topic of intense research. Intuitively, one would posit that disease-associated mutations of parkin result in the loss of its enzymatic activity. Although this is true for mutations that occur on parkin's RING2 domain, several groups including ours have demonstrated that the majority of parkin missense mutants outside its RING2 domain retain their catalytic competency (Chung et al., 2001; Hampe et al., 2006; Matsuda et al., 2006; Sriram et al., 2005; Wang et al., 2005). Instead, misfolding of parkin triggered by these mutations appears to be the major mechanism underlying parkin inactivation. Notably, missense parkin mutations frequently alter the protein solubility and concomitantly promote its aggregation into inclusion bodies (Ardley et al., 2003; Cookson et al., 2003; Gu et al., 2003; Hampe et al., 2006; Muqit et al., 2004; Sriram et al., 2005; Wang et al., 2005b). Amongst the aggregation-producing parkin mutations is the R275W substitution, which frequently occurs in the heterozygous state. Alternatively, some mutations of parkin compromise its function by destabilizing the protein and accelerating its degradation via the proteasome (Schlehe et al., 2008).

\subsection{Parkin-mediated ubiquitination and protein homeostasis}

As mentioned earlier, parkin functions as an E3 ligase associated with the UPS, a major proteolytic machinery that normally identifies and degrades unwanted intracellular proteins. In this system, proteins that are destined for proteasome-mediated degradation are added a chain of ubiquitin via a reaction cascade that involves the ubiquitin-activating (E1), -conjugating (E2) and -ligating (E3) enzymes. Through the sequential and repetitive actions of these enzymes, successive isopeptide linkages are formed between the C-terminal glycine carboxyl group (G76) of the ubiquitin moiety being added and the $\varepsilon$-amino group of a free lysine (most commonly K48) on the ubiquitin that is attached to the protein. The (G76-K48) polyubiquitinated substrate is then recognized by the $26 \mathrm{~S}$ proteasome as a target for degradation. It is important to highlight that the ubiquitin sequence contains seven lysine residues (at positions 6, 11, 27, 29, 33, 48 and 63) and that polyubiquitin chain assembly can 
occur at any of these lysine residues (Peng et al., 2003). In addition, proteins can also be monoubiquitinated. Notably, both K63-linked polyubiquitination and monoubiquitination of proteins are not typically associated with proteasome-mediated ubiquitination.

Shortly after the discovery of parkin as a PD-linked gene, three independent groups demonstrated that parkin-mediated ubiquitination is linked to protein degradation and that disease-associated parkin mutations compromise its role as an E3 enzyme (Imai et al., 2000; Shimura et al., 2000; Zhang et al., 2000). A logical and popular hypothesis that ensued is that loss of parkin function could lead to a toxic accumulation of one or several of its substrates, thereby leading to neurodegeneration. This had fuelled intense effort by many laboratories around the world to identify the culprit substrate(s) involved. To date, no less than 25 substrates (or putative substrates) of parkin has been reported since the identification of CDCrel1 as the first putative substrate for the ubiquitin ligase (Zhang et al., 2000) (Table 2). However, none of the parkin substrates identified thus far is exclusively expressed in DA neurons, which raises the question on why DA neurons in familial parkinsonism cases linked to parkin mutations are selectively vulnerable to deficient parkin function. Further, few from the laundry list fulfil an important criterion expected of an "authentic" parkin substrate: accumulation in the brains of ARJP patients and parkin-deficient models (Table 2). Although the pace of substrate identification has slowed down considerably in recent years, new parkin substrates continue to emerge periodically. Amongst the most recently isolated parkin substrates is the zinc fingercontaining protein called PARIS (ZNF746) (Shin et al., 2011), a major transcriptional repressor of PGC-1 $\alpha$ expression, which in turn regulates the transcription of many genes involved in cellular metabolism. Importantly, unlike most previously identified parkin substrates, PARIS accumulates in post-mortem brain tissues derived from ARJP and sporadic PD patients, as well as in the ventral midbrain region of mice that is conditionally ablated of parkin expression (Shin et al., 2011). Moreover, stereotactic injection of viral vector encoding PARIS into the SN of mice results in a selective loss of TH-positive DA neurons that can be rescued by either parkin or PGC-1 $\alpha$ co-expression (Shin et al., 2011). Together, these results suggest that PARIS is an "authentic" parkin substrate and that its upregulation may underlie neurodegeneration due to parkin inactivation. Notwithstanding this and the fact that a few other substrates have similarly been reported to fulfil the criterion of a parkin substrate (Table 2), what constitutes an "authentic" substrate for parkin is really debatable, as discussed below.

Although protein ubiquitination is classically associated with proteasome-mediated degradation, the existence of non-classic ubiquitin modifications such as K63-linked polyubiquitination would caution against the fixation on the traditional view that substrates of a ubiquitin ligase must exhibit an accelerated, proteasome-dependent turnover in the presence of the enzyme. This is particularly relevant to parkin, which we and others have demonstrated to be a multifunctional enzyme capable of mediating alternative ubiquitin topologies such as monoubiquitination and K63-linked polyubiquitination - modifications that are typically uncoupled from the proteasome and often considered as "non-proteolytic" (Doss-Pepe et al., 2005; Hampe et al., 2006; Lim et al., 2005; Matsuda et al., 2006) (Fig. 2). Our results would argue that the catalytic function of parkin is not limited to targeting substrate for degradation by the proteasome. Thus, the lack of accumulation of an identified parkin substrate in the brains of ARJP patients and parkin-deficient models does not necessarily mean that it is less than an "authentic" substrate. For example, we have previously reported that parkin-mediated polyubiquitination of synphilin-1 (an interactor of $\alpha$-synuclein) normally occurs via K63-linked chains, which does not appear to affect its steady-state turnover (Lim et al., 2005). Not surprisingly, the level of synphilin-1 is neither appreciably altered in ARJP brains nor in brain 
tissues derived from parkin null mice (Ko et al., 2005). A corollary to this is that proteasomeindependent pathways may also be relevant to parkin-related neurodegeneration.

\begin{tabular}{|c|c|c|c|c|c|}
\hline \multirow{2}{*}{ Substrates } & \multirow[t]{2}{*}{ Ub Type } & \multicolumn{3}{|c|}{ Elevated in } & \multirow[t]{2}{*}{ Reference } \\
\hline & & KO mice & ARJP Brain & PD brain & \\
\hline CDCrel-1 & - & Yes/No & Yes/No & - & (Ko et al., 2005) \\
\hline CDCrel-2a & - & - & Yes & - & (Choi et al., 2003) \\
\hline $\begin{array}{l}\text { Synaptotagmin } \\
\text { XI }\end{array}$ & - & Yes/No & - & - & (Periquet et al., 2005) \\
\hline Synphilin-1 & K63 & No & No & & $\begin{array}{l}\text { (Chung et al., 2001; Ko et } \\
\text { al., 2005; Lim et al., 2005) }\end{array}$ \\
\hline P38/AIMP2 & $\begin{array}{l}\text { Multiple } \\
\text { Mono }\end{array}$ & Yes & Yes & Yes & $\begin{array}{l}\text { (Corti et al., 2003; Hampe et } \\
\text { al., 2006; Ko et al., 2005; } \\
\text { Periquet et al., 2005) }\end{array}$ \\
\hline FBP1 & - & Yes & Yes & Yes & (Ko et al., 2006) \\
\hline PARIS (ZNF746) & K48 & Yes & Yes & Yes & (Shin et al., 2011) \\
\hline Cyclin E & - & No & Yes/No & Yes & $\begin{array}{l}\text { (Ko et al., 2005; Staropoli et } \\
\text { al., 2003) }\end{array}$ \\
\hline PDCP2-1 & - & - & Yes & Yes & (Fukae et al., 2009) \\
\hline Pael-R & - & No & Yes/No & - & (Ko et al., 2005) \\
\hline$\alpha / \beta$ tubulin & - & Yes/No & No & - & $\begin{array}{l}\text { (Ko et al., 2005; Ren et al., } \\
\text { 2003) }\end{array}$ \\
\hline Hsp70 & $\begin{array}{l}\text { Multiple } \\
\text { Mono }\end{array}$ & No & No & Yes & (Moore et al., 2008) \\
\hline PICK1 & Mono & No & - & - & (Joch et al., 2007) \\
\hline VDAC1 & $\begin{array}{l}\text { K27, } \\
\text { Mono }\end{array}$ & Yes & - & - & $\begin{array}{c}\text { (Geisler et al., 2010; } \\
\text { Narendra et al.; Periquet et } \\
\text { al., 2005) }\end{array}$ \\
\hline Ataxin-2 & - & Yes & - & - & (Huynh et al., 2007) \\
\hline $\begin{array}{l}O \text {-glycosylated } \\
\alpha \text {-synuclein }\end{array}$ & - & - & Yes & - & (Shimura et al., 2001) \\
\hline RanBP2 & - & - & - & - & (Um et al., 2006) \\
\hline Lim Kinase 1 & - & - & - & - & (Lim et al., 2007) \\
\hline Eps15 & Mono & - & - & - & (Fallon et al., 2006) \\
\hline DJ-1 L166P & K63 & - & - & - & (Olzmann et al., 2007) \\
\hline Bcl-2 & Mono & - & - & - & (Chen et al., 2010) \\
\hline Drp1 & K48 & - & - & - & (Wang et al., 2011) \\
\hline Mitofusin & - & - & - & - & $\begin{array}{c}\text { (Poole et al., 2010; Ziviani et } \\
\text { al., 2010) }\end{array}$ \\
\hline $\begin{array}{l}\text { Dopamine } \\
\text { Transporter }\end{array}$ & - & - & - & - & (Jiang et al., 2004) \\
\hline $\begin{array}{l}\text { Phospholipase } \\
C \gamma 1\end{array}$ & - & Yes & - & - & (Dehvari et al., 2009) \\
\hline Ataxin3 polyQ79 & - & - & - & - & (Tsai et al., 2003) \\
\hline
\end{tabular}

Table 2. List of parkin substrates/putative substrates 
By virtue of its apparent dissociation from the proteasome, we have originally proposed that parkin-mediated K63-linked ubiquitination may be involved in cargo diversion during proteasomal stress and accordingly, in the biogenesis of inclusion bodies associated with neurodegenerative diseases (Lim et al., 2006). Our proposal is consistent with the concept of aggresomes, which are juxtanuclear inclusion bodies formed in the presence of proteasomal stress and that have been suggested to act as staging grounds for the disposal of protein aggregates via the autophagic route (Kopito, 2000). Supporting our hypothesis, we found that parkin-mediated K63 polyubiquitination of synphilin-1 promotes its aggregation into aggresome-like inclusion bodies (Lim et al., 2005). Corroborating our findings, Olzmann et al demonstrated that parkin-mediated K63 polyubiquitination of misfolded DJ-1 couples the protein to the dynein motor complex via the histone deacetylase 6 (HDAC6) adaptor, thereby promoting its sequestration into aggresomes (Olzmann et al., 2007). Importantly, our recent work identified K63-linked polyubiquitin as a novel cargo selection signal for macroautophagy-mediated clearance of aggresomes (Tan et al., 2008a; Tan et al., 2008b). By being capable of mediating both proteasome-associated K48-polyubiquitination and macroautophagy-associated K63-linked polyubiquitination, parkin may potentially act as an important triage between the two major cellular degradation systems. This multifunctionality of parkin may in part help explain its apparent broad neuroprotective properties, as the flexibility of ubiquitin linkage usage presumably would allow the enzyme to adapt rapidly to changes in cellular environment.

\subsection{Parkin-mediated ubiquitination and mitochondrial homeostasis}

One of the first hints that parkin may play a role in mitochondrial homeostasis aside from its role as a regulator of protein turnover came from a study in fruit flies. Greene and colleagues analyzed adult Drosophila parkin null mutant and observed that the most prominent pathology is not in the brain but in the flight musculature of these mutant flies, which is plagued by muscle degeneration and pronounced mitochondrial lesions (Greene et al., 2003). Interestingly, PINK1 null flies were subsequently found to phenocopy their parkindeficient counterparts and importantly, parkin over expression in PINK1-/- flies is able to rescue all the mutant phenotypes tested, although the reverse, does not happen (Clark et al., 2006a; Park et al., 2006), suggesting that parkin acts in the same pathway but downstream of PINK1. We now know from several follow-up studies in flies and other model systems that the parkin/PINK1 pathway is a key regulator of mitochondrial dynamics, although it is currently controversial whether the pathway promotes mitochondrial fission or fusion [For a recent review, see (Burbulla et al., 2010)].

In an exciting development, Narendra and colleagues from Youle laboratory have recently demonstrated that parkin plays an essential role in removing damaged mitochondria from the cell via a specialized form of autophagy known as mitophagy (Narendra et al., 2008). This has fuelled widespread interest amongst many researchers directed at elucidating the mechanism underlying parkin-mediated mitophagy, which is reminiscent of the initial excitement shared by many to uncover novel parkin substrates. A model (Fig. 2) that has emerged from a flurry of follow-up studies proposed that a key initial event that occurs upon mitochondrial depolarization is the selective accumulation of PINK1 in the outer membrane of the damaged organelle (presumably after its segregation by fission). Notably, PINK1 accumulation in healthy mitochondria is prevented by a proteolytic event that rapidly cleaves the protein (Narendra et al., 2010; Vives-Bauza et al., 2010). Upon recruitment to depolarized mitochondria by PINK1, parkin then becomes activated 
(Matsuda et al., 2010) and promotes the ubiquitination and subsequent p97 AAA-ATPaseregulated degradation of mitofusins (Poole et al., 2010; Ziviani et al., 2010), the elimination of which will prevent unintended fusion events involving damaged mitochondria and thereby their re-entry into undamaged mitochondrial network from occurring (Tanaka et al., 2010). The event is then followed by the induction of mitophagy, which is also parkindependent. Parkin-mediated K63 ubiquitination is apparently important here, as mitochondrial substrates that are modified by K63 polyubiquitin can presumably help in the recruitment of autophagy receptors such as HDAC6 and p62 to the damaged organelle. Notably, both HDAC6 and p62 are ubiquitin-binding proteins that preferentially recognize K63 ubiquitin chains (Lim and Lim, 2010; Olzmann et al., 2007; Tan et al., 2008a). The end result is the formation of "mito-aggresomes" and their subsequent clearance by lysosomes. The whole process thus resembles the formation and autophagic clearance of aggresomes.

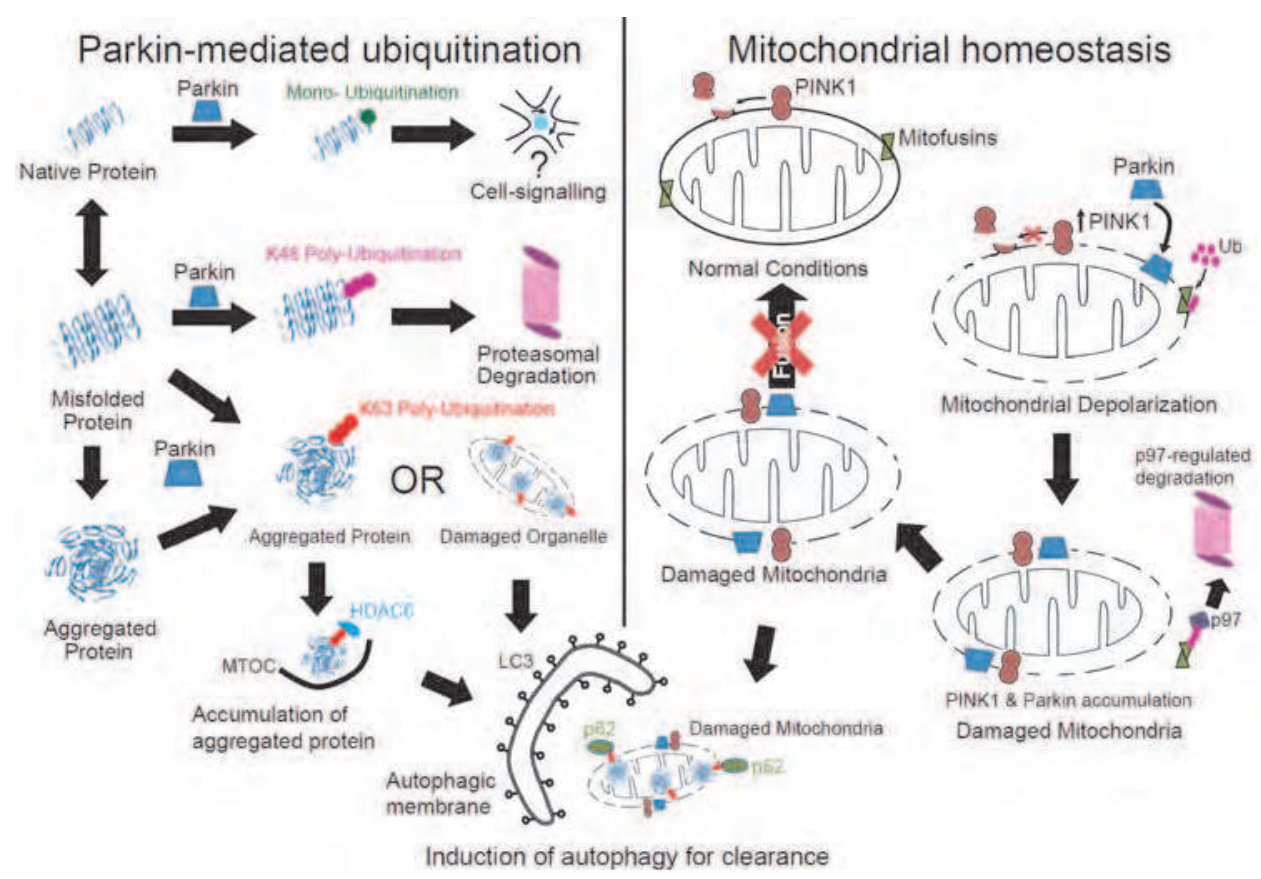

Fig. 2. Role of parkin in protein and mitochondrial QC. (Left) Parkin is a unique E3 enzyme capable of mediating various types of ubiquitin modification on its substrates that would result in different outcomes. (Right) A model of parkin/PINK1-mediated mitophagy.

Despite the logic and experimental support for the events surrounding parkin-mediated mitophagy as described above, the model is not without controversy. Because the majority of studies related to parkin-mediated mitophagy were carried out in cells grown in glucosecontaining medium, a potential confounding factor is that these cells generate most of their ATP via glycolysis from glucose present in the medium, and not via oxidative phosphorylation. Notably, mitophagy is blocked in yeast that are made obligatorily dependent on mitochondrial metabolism, even under severe starvation conditions (Kanki and Klionsky, 2008). According to a recent study by Van Laar and colleagues, parkin- 
mediated mitophagy does not seem to take place appreciably in primary neurons treated with mitochondrial uncouplers such as CCCP (Van Laar et al., 2011). Unlike other cell types, neurons are strictly dependent on mitochondrial respiration. In HeLa cells (grown in glucose medium) where parkin-mediated mitophagy was originally observed, the phenomenon is similarly attenuated when these cells were forced into dependence on mitochondrial respiration (i.e. cultured in glucose-free medium) (Van Laar et al., 2011). Thus, parkin-mediated mitophagy appears to be dependent on the bioenergetic status of the cell. Presumably, additional mechanisms are involved in the regulation of mitophagy in neurons and other cell types that derive their energy from oxidative phosphorylation. Notwithstanding this, it is important to highlight that at least two groups have found that parkin accumulation on mitochondria does occur in primary neurons treated with CCCP (Narendra et al., 2008; Vives-Bauza et al., 2010). The reason for this discrepancy is presently unclear, but the conundrum obviously needs to be resolved as whether parkin-mediated mitophagy takes place appreciably in neurons has significant implications for its role in PD pathogenesis.

Interestingly, parkin is also involved in mitochondrial biogenesis. Kuroda and colleagues previously demonstrated that parkin over-expression enhances the transcription and replication of mitochondrial DNA by associating with mitochondrial transcription factor A (TFAM) and promoting TFAM-mediated transcription (Kuroda et al., 2006). Accordingly, the event is attenuated by parkin expression silencing with siRNA. However, an important caveat is that parkin-induced mitochondrial biogenesis only occurs in proliferating but not differentiated cells (Kuroda et al., 2006). Hence, its relevance to post-mitotic cells like neurons is unclear. From the recent work by Shin and colleagues, we now know that parkin can also potentially regulate mitochondrial biogenesis by regulating PGC- $1 \alpha$ expression indirectly through its ability to down-regulate PARIS (which represses PGC-1 $\alpha$ expression) (Shin et al., 2011). PGC-1 $\alpha$ regulates a variety of genes that play important roles in mitochondrial biogenesis. Amongst these PGC-1 $\alpha$-regulated genes is nuclear respiratory factor-1 (NRF-1), whose activity contributes to the expression of respiratory subunits and mitochondrial transcription factors (Scarpulla, 2008). Notably, both PGC-1 $\alpha$ and NRF-1 expression are reduced in the SN of PD brains (Shin et al., 2011), suggesting that impaired renewal of neuronal mitochondria may contribute to DA neurodegeneration in parkinrelated cases. Based on these results, it is also logical to speculate that parkin might assist in the replenishment of exited mitochondria following extensive mitophagy. Thus, parkin appears to be involved in the entire spectrum of mitochondrial dynamics, i.e. from biogenesis to clearance.

\subsection{Parkin is a potent neuroprotectant}

Given the critical role of parkin in regulating protein and mitochondrial homeostasis, it is perhaps unsurprising to note that parkin is capable of protecting neurons against a wide variety of insults, including those mediated by $\alpha$-synuclein or mutant LRRK2, as well as those generated by dopamine quinones, neurotoxins or metallic ions (Feany and Pallanck, 2003; Winklhofer, 2007). Yet, it remains rather amazing at the same time to note that a single ubiquitin ligase could do all that. Moreover, several studies have also demonstrated that parkin can afford protection against neurotoxicity elicited by agents that are not directly related to PD. For example, parkin is apparently capable of mitigating cytotoxicity induced by $\beta$-amyloid or by expanded polyglutamine-containing proteins through facilitating their 
elimination from the cell (Rosen et al., 2010; Tsai et al., 2003). While the removal of aberrant proteins or damaged mitochondria from cells undergoing various forms of stress may be common denominators underlying the broad neuroprotective capacity of parkin, recent studies also implicated a more direct role for parkin in neuroprotective signalling. Indeed, parkin-mediated ubiquitination is important for the activation of major cellular pro-survival pathways such as the NF- $\kappa B$ pathway (Henn et al., 2007). Henn and colleagues demonstrated in cells treated with kainate (an excitotoxin) or rotenone (a mitochondrial complex I inhibitor) that parkin-mediated protection against cell death is dependent on NF$\kappa B$ activity (Henn et al., 2007). Interestingly, the authors further showed that the activation of NF-kB pathway by parkin is associated with its K63 polyubiquitination activity (Henn et al., 2007). Notably, several studies have also reported the ability of parkin to suppress stressrelated mitogen-activated protein kinase (MAPK) signalling (e.g. JNK and p38) (Cha et al., 2005; Ren et al., 2009), although the effect may be an indirect consequence of reduced oxidative stress level in the presence of parkin.

Besides its catalytic role, parkin can also promote neuroprotection in an ubiquitinationindependent manner. For example, Ren and colleagues have demonstrated that parkin does not require its ligase activity to stabilize microtubules and that this activity-independent function of parkin is important in the protection of DA neurons against microtubuledeploymerizing toxins (Ren et al., 2009). In a separate development, a provocative report suggested that parkin possesses ubiquitination-independent transcriptional activity, which in this case acts as a repressor of the tumor suppressor p53 expression. The repression of p53 expression by parkin ultimately leads to decreased Bax transcription, caspase 3 activity and apoptosis (da Costa et al., 2009). Although the subject of parkin's nuclear residency is currently still controversial, it is noteworthy that parkin localization to the nucleus has been independently observed by at least one other group (Kao, 2009a). Kao showed that parkin translocates to the nucleus following DNA damage (Kao, 2009a), apparently to assist in DNA repair (Kao, 2009b). Since parkin lacks a defined nucleus localization signal, precisely how the translocation of parkin occurs under different conditions remains to be elucidated. Notwithstanding the gaps in our current knowledge regarding the mechanisms underlying parkin-mediated protection, it is clear that parkin functions as a broad-spectrum neuroprotectant. Conceivably, parkin gene delivery could offer a novel avenue of PD therapy. Indeed, virus-mediated delivery of parkin has been shown to prevent DA neurodegeneration in rats either overexpressing $\alpha$-synuclein (Lo Bianco et al., 2004; Yamada et al., 2005) or treated with parkinsonian neurotoxins (Paterna et al., 2007), or in a nonhuman primate model of $\alpha$-synuclein overexpression (Yasuda et al., 2007). Another way to harness parkin's protective function is to look for molecules that can functionally compensate for loss of parkin function. Notably, Tain and colleagues have recently demonstrated that pharmacological activation of $4 E-B P$ (Thor) expression in parkin null flies by rapamycin can suppress all their pathologies (Tain et al., 2009), suggesting that rapamycin can somehow mimic parkin neuroprotection in the absence of the ubiquitin ligase.

\subsection{Mammalian models of parkin-related parkinsonism}

Given that parkin-related parkinsonism transmits in a largely recessive fashion and that parkin function is clearly important for neuronal homeostasis, one would intuitively be optimistic about generating a representative model of parkin-related parkinsonism through 
the ablation of endogenous parkin in animals. Although Drosophila parkin null mutants do exhibit prominent parkinsonian features (including DA neuronal loss and locomotive defects) that progress with age, germline-derived parkin knockout mice generally fail to exhibit robust signs of parkinsonism (Dawson et al., 2010; Perez and Palmiter, 2005). On the other hand, biochemical and proteomic analyses of brain samples prepared from these mice revealed deficits in dopamine handling, reduced mitochondrial respiration and antioxidant capacity, as well as increased ROS-mediated damage, all of which are consistent with the implicated cellular roles of parkin (Goldberg et al., 2003; Itier et al., 2003; Palacino et al., 2004). Conceivably, other proteins like PINK1 and DJ-1 that have overlapping functions with parkin may help to mitigate the overt manifestation of phenotypes in parkin null mice. However, it is noteworthy that even parkin/PINK1/DJ-1 triple knockout mice do not exhibit any evidence of nigral degeneration or dramatic pathology, at as late as 24 months of age (Kitada et al., 2009).

Why conventional parkin knockout mice (and for that matter the majority of genetic mouse models of PD generated via traditional means) consistently failed to produce significant nigral cell loss and associated phenotypes remains a puzzle, although the controlled environment that these animals frequently lived in may deny them the entry of unknown disease-promoting factor(s) that might be present in the environment at large. Notably, even individuals with overt parkin mutations typically require a few decades for the disease to surface, suggesting pathogenic interaction between genetic mutations and age-associated or other factors. Alternatively, compensatory mechanisms that kicked in during development may influence the onset of disease symptoms in humans and mouse alike. Supporting this, virus-mediated delivery of PD-linked genes into the $\mathrm{SN}$ of adult rodents via stereotactic injections, which effectively bypass developmental compensation, usually results in marked DA neurodegeneration (Ulusoy et al., 2008). As mentioned earlier, such an approach was taken by Shin and colleagues, who generated a conditional parkin knockout mice by which exon 7 of the parkin gene flanked by loxP sites was removed from the SN of adult mice following stereotactic injection of a Cre recombinase-containing lentiviral vector (Shin et al., 2011). This elegant approach leads to a dramatic loss of parkin expression from the ventral midbrain of injected mice that is accompanied by an age-dependent loss of DA neurons, although the motor parameters of these mice were not reported. Thus, loss of parkin function in adult mice does promote DA neuronal loss, albeit in a conditional-dependent manner. At the same time, the study also provided indirect evidence supporting that the pathogenicity arising from the loss of parkin function can be developmentally compensated (at least in mice). Such compensatory mechanisms may conceivably operate in humans and may account for the age-dependency and the heterogeneity of age of onset of PD. At the least, we now have a model of parkin-linked recessive parkinsonism that exhibits substantial and progressive nigral cell loss.

A different approach was taken by $\mathrm{Lu}$ and colleagues in modelling parkin dysfunction in mice. In view of the possibility that single parkin mutations may also contribute to the disease, the group developed a BAC (bacterial artificial chromosome) transgenic mouse model expressing a C-terminal truncated human mutant parkin (Parkin-Q311X) in DA neurons under the direction of a dopamine transporter promoter ( $\mathrm{Lu}$ et al., 2009). Expression of Parkin-Q311X, an aggregation-prone mutant, in mice produces age-dependent loss of SN DA neurons that is accompanied by progressive hypokinetic motor deficits. These results suggest that certain parkin mutants may exert direct neurotoxicity and support the 
role of heterozygous parkin mutations in disease pathogenesis. Notably, previous studies conducted in the Drosophila by the same group as well as by our group also arrived at the same suggestion (Sang et al., 2007; Wang et al., 2007). Indeed, transgenic flies expressing human parkin mutants such as R275W and Q311X display age-dependent, selective loss of DA neurons that is accompanied by progressive locomotion deficits (Sang et al., 2007; Wang et al., 2007).

\subsection{Relevance of parkin to sporadic PD}

That parkin mutations transmit in a recessive manner would suggest that the loss of parkin function predisposes DA neurons to degeneration. An important corollary to this is that any post-translational event that promotes the loss of parkin function could potentially mimic the effects brought about by overt mutations and be just as detrimental. Further, in view of the suggested contribution of parkin haploinsufficiency to disease risk, it is reasonable to assume that the down-regulation of normal parkin function mediated by such events need not result in the total abolition of its enzymatic activity to elicit a pathogenic effect.

We and others have found that a wide variety of PD-linked stressors, including those that produce oxidative and nitrosative stress, induce parkin solubility alterations and thereby its aggregation in a manner analogous to that brought about by several of its missense mutations (LaVoie et al., 2005; Wang et al., 2005; Winklhofer et al., 2003). Remarkably, dopamine also modifies parkin in a similar fashion (LaVoie et al., 2005; Wang et al., 2005). Furthermore, parkin appears to be uniquely susceptible to dopamine-induced modifications compared to several other related E3 members such as HHARI, Cbl and CHIP (LaVoie et al., 2007; LaVoie et al., 2005; Wong et al., 2007). Accordingly, detergent-insoluble parkin, but not HHARI, Cbl and CHIP, accumulates in the PD brain (LaVoie et al., 2005; Wang et al., 2005; Wong et al., 2007). As optimal level of soluble parkin is important for neuronal survival, the immobilization of the parkin within aggregates would not only deprive the protein of its function but also effectively reduce the pool of functional parkin available to the cell. Like haploinsufficiency, the biochemical depletion of soluble parkin levels is expected to increase the vulnerability of susceptible neurons to degeneration. Interestingly, normal parkin in the brain also becomes progressively more detergent-insoluble with aging (Pawlyk et al., 2003), which may provide an explanation to why age represents a risk factor for PD.

Besides stress-induced modifications, parkin phosphorylation is another post-translational modification that is linked to its inactivation. Notably, serine phosphorylation of parkin by casein kinase 1 (CK1) or cyclin-dependent kinase 5 (Cdk5) reportedly down-regulates its activity (Avraham et al., 2007; Yamamoto et al., 2005), and compound phosphorylation of parkin by both kinases further leads to its aggregation (Rubio de la Torre et al., 2009). While the physiological role of parkin phosphorylation remains unclear, it is conceivable that aberrant CK1 or Cdk5 activity can promote loss of parkin function and play a role in sporadic PD pathogenesis. Supporting this, parkin phosphorylation is elevated in distinct regions of sporadic PD brains and correlates with increased levels of p25, the activator of CDK5 (Rubio de la Torre et al., 2009). More recently, Ko and colleagues have demonstrated that tyrosine phosphorylation of parkin at residue 143 (Y143) by the src family kinase member, c-Abl, similarly inactivates its enzyme activity and compromises its protective function both in vitro and in vivo (Ko et al., 2010). They further showed that parkin is tyrosine-phosphorylated at Y143 in human post-mortem PD brains and that this modification of parkin is accompanied by the accumulation of parkin substrates such as 
AIMP2. Together, the results by Ko and colleagues suggest a pathophysiologic regulation of parkin by c-Abl in sporadic PD (Ko et al., 2010).

Other than the above-mentioned post-translational modifications, a number of parkin interactors have also been demonstrated to be capable of inactivating its E3 ligase activity. For example, the bcl-2-associated athanogene 5 (BAG5) associates with and inhibits parkin activity (Kalia et al., 2004). Further, BAG5 promotes the sequestration of parkin within protein aggregates and compromises its neuroprotective function. Accordingly, targeted expression of BAG5 in the SNpc of mice enhances DA neurodegeneration following axotomy-induced DA neuronal injury or MPTP administration (Kalia et al., 2004). Although the authors suggested that BAG5 may serve as a useful therapeutic target for PD, the mechanism by which BAG5 inhibits parkin E3 activity remains unclear to this date. It is also curious why DA neuronal injury would induce BAG5 expression, an event that inhibits rather than stimulates the neuroprotective activity of parkin, which invariably will worsen the condition. Notably, besides BAG5, several other parkin interactors have also been identified as modulators of its

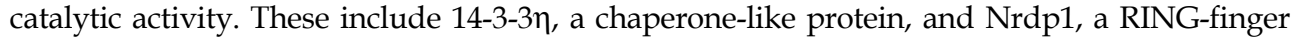
containing ubiquitin ligase (Sato et al., 2006; Zhong et al., 2005). Whereas 14-3-3 $\eta$ interacts with and reduces parkin activity directly (Sato et al., 2006), Nrdp1 promotes parkin degradation and depletes the availability of parkin to the cell (Zhong et al., 2005). Both events if unregulated would obviously be detrimental to parkin's protective function.

Taken together, it is apparent that loss of parkin function is not limited to those induced by disease-causing mutations, but also includes several biochemical and protein-protein modifications that can either alter the catalytic function of the E3 ligase directly, or indirectly through promoting its aggregation or degradation. Collectively, these mutationindependent modifications that inactivate parkin activity provide a mechanism for parkin dysfunction that is relevant to the pathogenesis of sporadic PD.

\section{Conclusion}

It is evident from the above discussion that parkin plays a key role in maintaining DA neuronal homeostasis and that its dysfunction is relevant to not just familial parkinsonism but also to sporadic PD. Parkin thus represents a neuroprotective PD-linked gene whose function can be and arguably should be exploited. Accordingly, a better understanding of parkin-mediated neuroprotective pathways would offer opportunities to uncover molecular targets that may be of therapeutic value to both familial and sporadic PD. The Drosophila model, with its powerful genetics as well as its amenability to drug screening, will be particularly useful here. Alternatively, given that the loss of parkin function can apparently be developmentally compensated (at least in mice), the identification and validation of components of the compensatory network will represent another approach to elucidate rational therapeutic strategies. Indeed, from a therapeutics point of view, it may be equally (if not more) beneficial to understand how parkin-related cases as well as PD in general are kept in check for decades before disease onset than to map the precise pathogenic events that occur after disease onset.

\section{Acknowledgment}

This work was supported by grants from A*STAR Biomedical Research Council, Khoo's Discovery Award, Singapore Millennium Foundation and the National University of 
Singapore (LKL). C.Y. and G.L. are supported by graduate scholarships from the Singapore Millennium Foundation. We thank Xiao-Hui Ng for illustrations.

\section{References}

Alexander, G. E. (2004). Biology of Parkinson's disease: pathogenesis and pathophysiology of a multisystem neurodegenerative disorder. Dialogues in Clinical Neuroscience, Vol.6, pp. 259-280.

Ardley, H. C., Scott, G. B., Rose, S. A., Tan, N. G., Markham, A. F. \& Robinson, P. A. (2003). Inhibition of proteasomal activity causes inclusion formation in neuronal and nonneuronal cells overexpressing Parkin. Mol Biol Cell, Vol.14, No.11, pp. 4541-4556.

Avraham, E., Rott, R., Liani, E., Szargel, R. \& Engelender, S. (2007). Phosphorylation of Parkin by the cyclin-dependent kinase 5 at the linker region modulates its ubiquitin-ligase activity and aggregation. J Biol Chem, Vol.282, No.17, pp. 1284212850.

Braak, H., Del Tredici, K., Rub, U., de Vos, R. A., Jansen Steur, E. N. \& Braak, E. (2003). Staging of brain pathology related to sporadic Parkinson's disease. Neurobiol Aging, Vol.24, No.2, pp. 197-211.

Buhmann, C., Binkofski, F., Klein, C., Buchel, C., van Eimeren, T., Erdmann, C., Hedrich, K., Kasten, M., Hagenah, J., Deuschl, G., Pramstaller, P. P. \& Siebner, H. R. (2005). Motor reorganization in asymptomatic carriers of a single mutant Parkin allele: a human model for presymptomatic parkinsonism. Brain, Vol.128, No.Pt 10, pp. 22812290.

Burbulla, L. F., Krebiehl, G. \& Kruger, R. (2010). Balance is the challenge--the impact of mitochondrial dynamics in Parkinson's disease. Eur J Clin Invest, Vol.40, No.11, pp. 1048-1060.

Cha, G. H., Kim, S., Park, J., Lee, E., Kim, M., Lee, S. B., Kim, J. M., Chung, J. \& Cho, K. S. (2005). Parkin negatively regulates JNK pathway in the dopaminergic neurons of Drosophila. Proc Natl Acad Sci U S A, Vol.102, No.29, pp. 10345-10350.

Chen, D., Gao, F., Li, B., Wang, H., Xu, Y., Zhu, C. \& Wang, G. (2010). Parkin Monoubiquitinates Bcl-2 and Regulates Autophagy. Journal of Biological Chemistry, Vol.285, No.49, pp. 38214-38223.

Choi, P., Snyder, H., Petrucelli, L., Theisler, C., Chong, M., Zhang, Y., Lim, K., Chung, K. K. K., Kehoe, K., D'Adamio, L., Lee, J. M., Cochran, E., Bowser, R., Dawson, T. M. \& Wolozin, B. (2003). SEPT5_v2 is a parkin-binding protein. Molecular Brain Research, Vol.117, No.2, pp. 179-189.

Chung, K. K., Zhang, Y., Lim, K. L., Tanaka, Y., Huang, H., Gao, J., Ross, C. A., Dawson, V. L. \& Dawson, T. M. (2001). Parkin ubiquitinates the alpha-synuclein-interacting protein, synphilin-1: implications for Lewy-body formation in Parkinson disease. Nat Med, Vol.7, No.10, pp. 1144-1150.

Clark, I. E., Dodson, M. W., Jiang, C., Cao, J. H., Huh, J. R., Seol, J. H., Yoo, S. J., Hay, B. A. \& Guo, M. (2006a). Drosophila pink1 is required for mitochondrial function and interacts genetically with parkin. Nature, Vol.441, No.7097, pp. 1162-1166.

Clark, L. N., Afridi, S., Karlins, E., Wang, Y., Mejia-Santana, H., Harris, J., Louis, E. D., Cote, L. J., Andrews, H., Fahn, S., Waters, C., Ford, B., Frucht, S., Ottman, R. \& Marder, K. (2006b). Case-control study of the parkin gene in early-onset Parkinson disease. Arch Neurol, Vol.63, No.4, pp. 548-552. 
Cookson, M. R., Lockhart, P. J., McLendon, C., O'Farrell, C., Schlossmacher, M. \& Farrer, M. J. (2003). RING finger 1 mutations in Parkin produce altered localization of the protein. Hum Mol Genet, Vol.12, No.22, pp. 2957-2965.

Corti, O., Hampe, C., Koutnikova, H., Darios, F., Jacquier, S., Prigent, A., Robinson, J. C., Pradier, L., Ruberg, M., Mirande, M., Hirsch, E., Rooney, T., Fournier, A. \& Brice, A. (2003). The p38 subunit of the aminoacyl-tRNA synthetase complex is a Parkin substrate: linking protein biosynthesis and neurodegeneration. Hum Mol Genet, Vol.12, No.12, pp. 1427-1437.

da Costa, C. A., Sunyach, C., Giaime, E., West, A., Corti, O., Brice, A., Safe, S., AbouSleiman, P. M., Wood, N. W., Takahashi, H., Goldberg, M. S., Shen, J. \& Checler, F. (2009). Transcriptional repression of p53 by parkin and impairment by mutations associated with autosomal recessive juvenile Parkinson's disease. Nat Cell Biol, Vol.11, No.11, pp. 1370-1375.

Dawson, T. M., Ko, H. S. \& Dawson, V. L. (2010). Genetic animal models of Parkinson's disease. Neuron, Vol.66, No.5, pp. 646-661.

Dehvari, N., Sandebring, A., Flores-Morales, A., Mateos, L., Chuan, Y.-C., Goldberg, M. S., Cookson, M. R., Cowburn, R. F. \& Cedazo-Mínguez, A. (2009). Parkin-mediated ubiquitination regulates phospholipase C- $\gamma 1$. Journal of Cellular and Molecular Medicine, Vol.13, No.9b, pp. 3061-3068.

Di Fonzo, A., Dekker, M. C., Montagna, P., Baruzzi, A., Yonova, E. H., Correia Guedes, L., Szczerbinska, A., Zhao, T., Dubbel-Hulsman, L. O., Wouters, C. H., de Graaff, E., Oyen, W. J., Simons, E. J., Breedveld, G. J., Oostra, B. A., Horstink, M. W. \& Bonifati, V. (2009). FBXO7 mutations cause autosomal recessive, early-onset parkinsonian-pyramidal syndrome. Neurology, Vol.72, No.3, pp. 240-245.

Dorsey, E. R., Constantinescu, R., Thompson, J. P., Biglan, K. M., Holloway, R. G., Kieburtz, K., Marshall, F. J., Ravina, B. M., Schifitto, G., Siderowf, A. \& Tanner, C. M. (2007). Projected number of people with Parkinson disease in the most populous nations, 2005 through 2030. Neurology, Vol.68, No.5, pp. 384-386.

Doss-Pepe, E. W., Chen, L. \& Madura, K. (2005). Alpha-synuclein and parkin contribute to the assembly of ubiquitin lysine 63-linked multiubiquitin chains. J Biol Chem, Vol.280, No.17, pp. 16619-16624.

Fallon, L., Belanger, C. M. L., Corera, A. T., Kontogiannea, M., Regan-Klapisz, E., Moreau, F., Voortman, J., Haber, M., Rouleau, G., Thorarinsdottir, T., Brice, A., van Bergen en Henegouwen, P. M. P. \& Fon, E. A. (2006). A regulated interaction with the UIM protein Eps15 implicates parkin in EGF receptor trafficking and PI(3)K-Akt signalling. Nat Cell Biol, Vol.8, No.8, pp. 834-842.

Farrer, M., Chan, P., Chen, R., Tan, L., Lincoln, S., Hernandez, D., Forno, L., Gwinn-Hardy, K., Petrucelli, L., Hussey, J., Singleton, A., Tanner, C., Hardy, J. \& Langston, J. W. (2001). Lewy bodies and parkinsonism in families with parkin mutations. Ann Neurol, Vol.50, No.3, pp. 293-300.

Feany, M. B. \& Pallanck, L. J. (2003). Parkin: a multipurpose neuroprotective agent? Neuron, Vol.38, No.1, pp. 13-16.

Fukae, J., Sato, S., Shiba, K., Sato, K.-i., Mori, H., Sharp, P. A., Mizuno, Y. \& Hattori, N. (2009). Programmed cell death-2 isoform1 is ubiquitinated by parkin and increased in the substantia nigra of patients with autosomal recessive Parkinson's disease. FEBS Letters, Vol.583, No.3, pp. 521-525. 
Geisler, S., Holmstrom, K. M., Skujat, D., Fiesel, F. C., Rothfuss, O. C., Kahle, P. J. \& Springer, W. (2010). PINK1/Parkin-mediated mitophagy is dependent on VDAC1 and p62/SQSTM1. Nat Cell Biol, Vol.12, No.2, pp. 119-131.

Goldberg, M. S., Fleming, S. M., Palacino, J. J., Cepeda, C., Lam, H. A., Bhatnagar, A., Meloni, E. G., Wu, N., Ackerson, L. C., Klapstein, G. J., Gajendiran, M., Roth, B. L., Chesselet, M. F., Maidment, N. T., Levine, M. S. \& Shen, J. (2003). Parkin-deficient mice exhibit nigrostriatal deficits but not loss of dopaminergic neurons. J Biol Chem, Vol.278, No.44, pp. 43628-43635.

Greene, J. C., Whitworth, A. J., Kuo, I., Andrews, L. A., Feany, M. B. \& Pallanck, L. J. (2003). Mitochondrial pathology and apoptotic muscle degeneration in Drosophila parkin mutants. Proc Natl Acad Sci U S A, Vol.100, No.7, pp. 4078-4083.

Gu, W. J., Corti, O., Araujo, F., Hampe, C., Jacquier, S., Lucking, C. B., Abbas, N., Duyckaerts, C., Rooney, T., Pradier, L., Ruberg, M. \& Brice, A. (2003). The C289G and $\mathrm{C} 418 \mathrm{R}$ missense mutations cause rapid sequestration of human Parkin into insoluble aggregates. Neurobiol Dis, Vol.14, No.3, pp. 357-364.

Hampe, C., Ardila-Osorio, H., Fournier, M., Brice, A. \& Corti, O. (2006). Biochemical analysis of Parkinson's disease-causing variants of Parkin, an E3 ubiquitin-protein ligase with monoubiquitylation capacity. Hum Mol Genet, Vol.15, No.13, pp. 20592075.

Hayashi, S., Wakabayashi, K., Ishikawa, A., Nagai, H., Saito, M., Maruyama, M., Takahashi, T., Ozawa, T., Tsuji, S. \& Takahashi, H. (2000). An autopsy case of autosomalrecessive juvenile parkinsonism with a homozygous exon 4 deletion in the parkin gene. Mov Disord, Vol.15, No.5, pp. 884-888.

Healy, D. G., Abou-Sleiman, P. M. \& Wood, N. W. (2004). Genetic causes of Parkinson's disease: UCHL-1. Cell Tissue Res, Vol.318, No.1, pp. 189-194.

Hedrich, K., Eskelson, C., Wilmot, B., Marder, K., Harris, J., Garrels, J., Meija-Santana, H., Vieregge, P., Jacobs, H., Bressman, S. B., Lang, A. E., Kann, M., Abbruzzese, G., Martinelli, P., Schwinger, E., Ozelius, L. J., Pramstaller, P. P., Klein, C. \& Kramer, P. (2004). Distribution, type, and origin of Parkin mutations: review and case studies. Mov Disord, Vol.19, No.10, pp. 1146-1157.

Henn, I. H., Bouman, L., Schlehe, J. S., Schlierf, A., Schramm, J. E., Wegener, E., Nakaso, K., Culmsee, C., Berninger, B., Krappmann, D., Tatzelt, J. \& Winklhofer, K. F. (2007). Parkin mediates neuroprotection through activation of IkappaB kinase/nuclear factor-kappaB signaling. J Neurosci, Vol.27, No.8, pp. 1868-1878.

Hilker, R., Klein, C., Ghaemi, M., Kis, B., Strotmann, T., Ozelius, L. J., Lenz, O., Vieregge, P., Herholz, K., Heiss, W. D. \& Pramstaller, P. P. (2001). Positron emission tomographic analysis of the nigrostriatal dopaminergic system in familial parkinsonism associated with mutations in the parkin gene. Ann Neurol, Vol.49, No.3, pp. 367-376.

Huynh, D. P., Nguyen, D. T., Pulst-Korenberg, J. B., Brice, A. \& Pulst, S. M. (2007). Parkin is an E3 ubiquitin-ligase for normal and mutant ataxin-2 and prevents ataxin-2induced cell death. Experimental Neurology, Vol.203, No.2, pp. 531-541.

Imai, Y., Soda, M. \& Takahashi, R. (2000). Parkin suppresses unfolded protein stress-induced cell death through its E3 ubiquitin-protein ligase activity. J Biol Chem, Vol.275, No.46, pp. 35661-35664. 
Itier, J. M., Ibanez, P., Mena, M. A., Abbas, N., Cohen-Salmon, C., Bohme, G. A., Laville, M., Pratt, J., Corti, O., Pradier, L., Ret, G., Joubert, C., Periquet, M., Araujo, F., Negroni, J., Casarejos, M. J., Canals, S., Solano, R., Serrano, A., Gallego, E., Sanchez, M., Denefle, P., Benavides, J., Tremp, G., Rooney, T. A., Brice, A. \& Garcia de Yebenes, J. (2003). Parkin gene inactivation alters behaviour and dopamine neurotransmission in the mouse. Hum Mol Genet, Vol.12, No.18, pp. 2277-2291.

Jiang, H., Jiang, Q. \& Feng, J. (2004). Parkin Increases Dopamine Uptake by Enhancing the Cell Surface Expression of Dopamine Transporter. Journal of Biological Chemistry, Vol.279, No.52, pp. 54380-54386.

Joch, M., Ase, A. R., Chen, C. X. Q., MacDonald, P. A., Kontogiannea, M., Corera, A. T., Brice, A., Seguela, P. \& Fon, E. A. (2007). Parkin-mediated Monoubiquitination of the PDZ Protein PICK1 Regulates the Activity of Acid-sensing Ion Channels. Mol. Biol. Cell, Vol.18, No.8, pp. 3105-3118.

Kalia, S. K., Lee, S., Smith, P. D., Liu, L., Crocker, S. J., Thorarinsdottir, T. E., Glover, J. R., Fon, E. A., Park, D. S. \& Lozano, A. M. (2004). BAG5 inhibits parkin and enhances dopaminergic neuron degeneration. Neuron, Vol.44, No.6, pp. 931-945.

Kanki, T. \& Klionsky, D. J. (2008). Mitophagy in yeast occurs through a selective mechanism. J Biol Chem, Vol.283, No.47, pp. 32386-32393.

Kao, S. Y. (2009a). DNA damage induces nuclear translocation of parkin. J Biomed Sci, Vol.16, pp. 67.

Kao, S. Y. (2009b). Regulation of DNA repair by parkin. Biochem Biophys Res Commun, Vol.382, No.2, pp. 321-325.

Kay, D. M., Moran, D., Moses, L., Poorkaj, P., Zabetian, C. P., Nutt, J., Factor, S. A., Yu, C. E., Montimurro, J. S., Keefe, R. G., Schellenberg, G. D. \& Payami, H. (2007). Heterozygous parkin point mutations are as common in control subjects as in Parkinson's patients. Ann Neurol, Vol.61, No.1, pp. 47-54.

Kitada, T., Asakawa, S., Hattori, N., Matsumine, H., Yamamura, Y., Minoshima, S., Yokochi, M., Mizuno, Y. \& Shimizu, N. (1998). Mutations in the parkin gene cause autosomal recessive juvenile parkinsonism. Nature, Vol.392, No.6676, pp. 605-608.

Kitada, T., Tong, Y., Gautier, C. A. \& Shen, J. (2009). Absence of nigral degeneration in aged parkin/DJ-1/PINK1 triple knockout mice. J Neurochem, Vol.111, No.3, pp. 696-702.

Klein, C., Lohmann-Hedrich, K., Rogaeva, E., Schlossmacher, M. G. \& Lang, A. E. (2007). Deciphering the role of heterozygous mutations in genes associated with parkinsonism. Lancet Neurol, Vol.6, No.7, pp. 652-662.

Ko, H. S., Kim, S. W., Sriram, S. R., Dawson, V. L. \& Dawson, T. M. (2006). Identification of Far Upstream Element-binding Protein-1 as an Authentic Parkin Substrate. J. Biol. Chem., Vol.281, No.24, pp. 16193-16196.

Ko, H. S., Lee, Y., Shin, J. H., Karuppagounder, S. S., Gadad, B. S., Koleske, A. J., Pletnikova, O., Troncoso, J. C., Dawson, V. L. \& Dawson, T. M. (2010). Phosphorylation by the c-Abl protein tyrosine kinase inhibits parkin's ubiquitination and protective function. Proc Natl Acad Sci U S A, Vol.107, No.38, pp. 16691-16696.

Ko, H. S., von Coelln, R., Sriram, S. R., Kim, S. W., Chung, K. K., Pletnikova, O., Troncoso, J., Johnson, B., Saffary, R., Goh, E. L., Song, H., Park, B. J., Kim, M. J., Kim, S., Dawson, V. L. \& Dawson, T. M. (2005). Accumulation of the authentic parkin substrate aminoacyl-tRNA synthetase cofactor, p38/JTV-1, leads to catecholaminergic cell death. J Neurosci, Vol.25, No.35, pp. 7968-7978. 
Kopito, R. R. (2000). Aggresomes, inclusion bodies and protein aggregation. Trends Cell Biol, Vol.10, No.12, pp. 524-530.

Kuroda, Y., Mitsui, T., Kunishige, M., Shono, M., Akaike, M., Azuma, H. \& Matsumoto, T. (2006). Parkin enhances mitochondrial biogenesis in proliferating cells. Hum Mol Genet, Vol.15, No.6, pp. 883-895.

LaVoie, M. J., Cortese, G. P., Ostaszewski, B. L. \& Schlossmacher, M. G. (2007). The effects of oxidative stress on parkin and other E3 ligases. J Neurochem, Vol.103, No.6, pp. 2354-2368.

LaVoie, M. J., Ostaszewski, B. L., Weihofen, A., Schlossmacher, M. G. \& Selkoe, D. J. (2005). Dopamine covalently modifies and functionally inactivates parkin. Nat Med, Vol.11, No.11, pp. 1214-1221.

Lim, K. L., Chew, K. C., Tan, J. M., Wang, C., Chung, K. K., Zhang, Y., Tanaka, Y., Smith, W., Engelender, S., Ross, C. A., Dawson, V. L. \& Dawson, T. M. (2005). Parkin mediates nonclassical, proteasomal-independent ubiquitination of synphilin-1: implications for Lewy body formation. J Neurosci, Vol.25, No.8, pp. 2002-2009.

Lim, K. L., Dawson, V. L. \& Dawson, T. M. (2006). Parkin-mediated lysine 63-linked polyubiquitination: a link to protein inclusions formation in Parkinson's and other conformational diseases? Neurobiol Aging, Vol.27, No.4, pp. 524-529.

Lim, K. L. \& Lim, G. G. (2011). K63-linked ubiquitination and neurodegeneration. Neurobiol Dis, 43, 9-16.

Lim, M. K., Kawamura, T., Ohsawa, Y., Ohtsubo, M., Asakawa, S., Takayanagi, A. \& Shimizu, N. (2007). Parkin interacts with LIM Kinase 1 and reduces its cofilinphosphorylation activity via ubiquitination. Experimental cell research, Vol.313, No.13, pp. 2858-2874.

Lincoln, S. J., Maraganore, D. M., Lesnick, T. G., Bounds, R., de Andrade, M., Bower, J. H., Hardy, J. A. \& Farrer, M. J. (2003). Parkin variants in North American Parkinson's disease: cases and controls. Mov Disord, Vol.18, No.11, pp. 1306-1311.

Lo Bianco, C., Schneider, B. L., Bauer, M., Sajadi, A., Brice, A., Iwatsubo, T. \& Aebischer, P. (2004). Lentiviral vector delivery of parkin prevents dopaminergic degeneration in an alpha-synuclein rat model of Parkinson's disease. Proc Natl Acad Sci U S A, Vol.101, No.50, pp. 17510-17515.

Lu, X. H., Fleming, S. M., Meurers, B., Ackerson, L. C., Mortazavi, F., Lo, V., Hernandez, D., Sulzer, D., Jackson, G. R., Maidment, N. T., Chesselet, M. F. \& Yang, X. W. (2009). Bacterial artificial chromosome transgenic mice expressing a truncated mutant parkin exhibit age-dependent hypokinetic motor deficits, dopaminergic neuron degeneration, and accumulation of proteinase K-resistant alpha-synuclein. $J$ Neurosci, Vol.29, No.7, pp. 1962-1976.

Lucking, C. B., Durr, A., Bonifati, V., Vaughan, J., De Michele, G., Gasser, T., Harhangi, B. S., Meco, G., Denefle, P., Wood, N. W., Agid, Y. \& Brice, A. (2000). Association between early-onset Parkinson's disease and mutations in the parkin gene. French Parkinson's Disease Genetics Study Group. N Engl J Med, Vol.342, No.21, pp. 15601567.

Mata, I. F., Lockhart, P. J. \& Farrer, M. J. (2004). Parkin genetics: one model for Parkinson's disease. Hum Mol Genet, Vol.13 Spec No 1, pp. R127-133. 
Matsuda, N., Kitami, T., Suzuki, T., Mizuno, Y., Hattori, N. \& Tanaka, K. (2006). Diverse effects of pathogenic mutations of Parkin that catalyze multiple monoubiquitylation in vitro. J Biol Chem, Vol.281, No.6, pp. 3204-3209.

Matsuda, N., Sato, S., Shiba, K., Okatsu, K., Saisho, K., Gautier, C. A., Sou, Y. S., Saiki, S., Kawajiri, S., Sato, F., Kimura, M., Komatsu, M., Hattori, N. \& Tanaka, K. (2010). PINK1 stabilized by mitochondrial depolarization recruits Parkin to damaged mitochondria and activates latent Parkin for mitophagy. J Cell Biol, Vol.189, No.2, pp. 211-221.

Moore, D. J., West, A. B., Dikeman, D. A., Dawson, V. L. \& Dawson, T. M. (2008). Parkin mediates the degradation-independent ubiquitination of Hsp70. J Neurochem, Vol.105, No.5, pp. 1806-1819.

Mori, H., Kondo, T., Yokochi, M., Matsumine, H., Nakagawa-Hattori, Y., Miyake, T., Suda, K. \& Mizuno, Y. (1998). Pathologic and biochemical studies of juvenile parkinsonism linked to chromosome 6q. Neurology, Vol.51, No.3, pp. 890-892.

Muqit, M. M., Davidson, S. M., Payne Smith, M. D., MacCormac, L. P., Kahns, S., Jensen, P. H., Wood, N. W. \& Latchman, D. S. (2004). Parkin is recruited into aggresomes in a stress-specific manner: over-expression of parkin reduces aggresome formation but can be dissociated from parkin's effect on neuronal survival. Hum Mol Genet, Vol.13, No.1, pp. 117-135.

Narendra, D., Tanaka, A., Suen, D. F. \& Youle, R. J. (2008). Parkin is recruited selectively to impaired mitochondria and promotes their autophagy. J Cell Biol, Vol.183, No.5, pp. 795-803.

Narendra, D. P., Jin, S. M., Tanaka, A., Suen, D. F., Gautier, C. A., Shen, J., Cookson, M. R. \& Youle, R. J. (2010). PINK1 is selectively stabilized on impaired mitochondria to activate Parkin. PLoS Biol, Vol.8, No.1, pp. e1000298.

Narendra, D. P., Kane, L. A., Hauser, D. N., Fearnley, I. M. \& Youle, R. J. p62/SQSTM1 is required for Parkin-induced mitochondrial clustering but not mitophagy; VDAC1 is dispensable for both. Autophagy, Vol.6, No.8.

Olanow, C. W., Hauser, R. A., Jankovic, J., Langston, W., Lang, A., Poewe, W., Tolosa, E., Stocchi, F., Melamed, E., Eyal, E. \& Rascol, O. (2008). A randomized, double-blind, placebo-controlled, delayed start study to assess rasagiline as a disease modifying therapy in Parkinson's disease (the ADAGIO study): rationale, design, and baseline characteristics. Mov Disord, Vol.23, No.15, pp. 2194-2201.

Olzmann, J. A., Li, L., Chudaev, M. V., Chen, J., Perez, F. A., Palmiter, R. D. \& Chin, L. S. (2007). Parkin-mediated K63-linked polyubiquitination targets misfolded DJ-1 to aggresomes via binding to HDAC6. J Cell Biol, Vol.178, No.6, pp. 1025-1038.

Paisan-Ruiz, C., Bhatia, K. P., Li, A., Hernandez, D., Davis, M., Wood, N. W., Hardy, J., Houlden, H., Singleton, A. \& Schneider, S. A. (2009). Characterization of PLA2G6 as a locus for dystonia-parkinsonism. Ann Neurol, Vol.65, No.1, pp. 19-23.

Palacino, J. J., Sagi, D., Goldberg, M. S., Krauss, S., Motz, C., Wacker, M., Klose, J. \& Shen, J. (2004). Mitochondrial dysfunction and oxidative damage in parkin-deficient mice. J Biol Chem, Vol.279, No.18, pp. 18614-18622.

Park, J., Lee, S. B., Lee, S., Kim, Y., Song, S., Kim, S., Bae, E., Kim, J., Shong, M., Kim, J. M. \& Chung, J. (2006). Mitochondrial dysfunction in Drosophila PINK1 mutants is complemented by parkin. Nature, Vol.441, No.7097, pp. 1157-1161. 
Paterna, J. C., Leng, A., Weber, E., Feldon, J. \& Bueler, H. (2007). DJ-1 and Parkin Modulate Dopamine-dependent Behavior and Inhibit MPTP-induced Nigral Dopamine Neuron Loss in Mice. Mol Ther.

Pawlyk, A. C., Giasson, B. I., Sampathu, D. M., Perez, F. A., Lim, K. L., Dawson, V. L., Dawson, T. M., Palmiter, R. D., Trojanowski, J. Q. \& Lee, V. M. (2003). Novel monoclonal antibodies demonstrate biochemical variation of brain parkin with age. J Biol Chem, Vol.278, No.48, pp. 48120-48128.

Peng, J., Schwartz, D., Elias, J. E., Thoreen, C. C., Cheng, D., Marsischky, G., Roelofs, J., Finley, D. \& Gygi, S. P. (2003). A proteomics approach to understanding protein ubiquitination. Nat Biotechnol, Vol.21, No.8, pp. 921-926.

Perez, F. A. \& Palmiter, R. D. (2005). Parkin-deficient mice are not a robust model of parkinsonism. Proc Natl Acad Sci U S A, Vol.102, No.6, pp. 2174-2179.

Periquet, M., Corti, O., Jacquier, S. \& Brice, A. (2005). Proteomic analysis of parkin knockout mice: alterations in energy metabolism, protein handling and synaptic function. Journal of Neurochemistry, Vol.95, No.5, pp. 1259-1276.

Periquet, M., Latouche, M., Lohmann, E., Rawal, N., De Michele, G., Ricard, S., Teive, H., Fraix, V., Vidailhet, M., Nicholl, D., Barone, P., Wood, N. W., Raskin, S., Deleuze, J. F., Agid, Y., Durr, A. \& Brice, A. (2003). Parkin mutations are frequent in patients with isolated early-onset parkinsonism. Brain, Vol.126, No.Pt 6, pp. 1271-1278.

Poole, A. C., Thomas, R. E., Yu, S., Vincow, E. S. \& Pallanck, L. (2010). The mitochondrial fusion-promoting factor mitofusin is a substrate of the PINK1/parkin pathway. PLoS One, Vol.5, No.4, pp. e10054.

Pramstaller, P. P., Schlossmacher, M. G., Jacques, T. S., Scaravilli, F., Eskelson, C., Pepivani, I., Hedrich, K., Adel, S., Gonzales-McNeal, M., Hilker, R., Kramer, P. L. \& Klein, C. (2005). Lewy body Parkinson's disease in a large pedigree with 77 Parkin mutation carriers. Ann Neurol, Vol.58, No.3, pp. 411-422.

Ramirez, A., Heimbach, A., Grundemann, J., Stiller, B., Hampshire, D., Cid, L. P., Goebel, I., Mubaidin, A. F., Wriekat, A. L., Roeper, J., Al-Din, A., Hillmer, A. M., Karsak, M., Liss, B., Woods, C. G., Behrens, M. I. \& Kubisch, C. (2006). Hereditary parkinsonism with dementia is caused by mutations in ATP13A2, encoding a lysosomal type 5 Ptype ATPase. Nat Genet, Vol.38, No.10, pp. 1184-1191.

Ren, Y., Jiang, H., Yang, F., Nakaso, K. \& Feng, J. (2009). Parkin protects dopaminergic neurons against microtubule-depolymerizing toxins by attenuating microtubuleassociated protein kinase activation. J Biol Chem, Vol.284, No.6, pp. 4009-4017.

Ren, Y., Zhao, J. \& Feng, J. (2003). Parkin binds to alpha/beta tubulin and increases their ubiquitination and degradation. J Neurosci, Vol.23, No.8, pp. 3316-3324.

Rosen, K. M., Moussa, C. E., Lee, H. K., Kumar, P., Kitada, T., Qin, G., Fu, Q. \& Querfurth, H. W. (2010). Parkin reverses intracellular beta-amyloid accumulation and its negative effects on proteasome function. J Neurosci Res, Vol.88, No.1, pp. 167-178.

Rubio de la Torre, E., Luzon-Toro, B., Forte-Lago, I., Minguez-Castellanos, A., Ferrer, I. \& Hilfiker, S. (2009). Combined kinase inhibition modulates parkin inactivation. Hum Mol Genet, Vol.18, No.5, pp. 809-823.

Sang, T. K., Chang, H. Y., Lawless, G. M., Ratnaparkhi, A., Mee, L., Ackerson, L. C., Maidment, N. T., Krantz, D. E. \& Jackson, G. R. (2007). A Drosophila model of mutant human parkin-induced toxicity demonstrates selective loss of dopaminergic 
neurons and dependence on cellular dopamine. J Neurosci, Vol.27, No.5, pp. 981992.

Sato, S., Chiba, T., Sakata, E., Kato, K., Mizuno, Y., Hattori, N. \& Tanaka, K. (2006). 14-3-3eta is a novel regulator of parkin ubiquitin ligase. EMBO J, Vol.25, No.1, pp. 211-221.

Scarpulla, R. C. (2008). Nuclear control of respiratory chain expression by nuclear respiratory factors and PGC-1-related coactivator. Ann N Y Acad Sci, Vol.1147, pp. 321-334.

Schlehe, J. S., Lutz, A. K., Pilsl, A., Lammermann, K., Grgur, K., Henn, I. H., Tatzelt, J. \& Winklhofer, K. F. (2008). Aberrant folding of pathogenic Parkin mutants: aggregation versus degradation. J Biol Chem, Vol.283, No.20, pp. 13771-13779.

Shimura, H., Hattori, N., Kubo, S., Mizuno, Y., Asakawa, S., Minoshima, S., Shimizu, N., Iwai, K., Chiba, T., Tanaka, K. \& Suzuki, T. (2000). Familial Parkinson disease gene product, parkin, is a ubiquitin-protein ligase. Nat Genet, Vol.25, No.3, pp. 302-305.

Shimura, H., Schlossmacher, M. G., Hattori, N., Frosch, M. P., Trockenbacher, A., Schneider, R., Mizuno, Y., Kosik, K. S. \& Selkoe, D. J. (2001). Ubiquitination of a New Form of alpha -Synuclein by Parkin from Human Brain: Implications for Parkinson's Disease. Science, Vol.293, No.5528, pp. 263-269.

Shin, J. H., Ko, H. S., Kang, H., Lee, Y., Lee, Y. I., Pletinkova, O., Troconso, J. C., Dawson, V. L. \& Dawson, T. M. (2011). PARIS (ZNF746) Repression of PGC-1alpha Contributes to Neurodegeneration in Parkinson's Disease. Cell, Vol.144, No.5, pp. 689-702.

Simon-Sanchez, J. \& Singleton, A. B. (2008). Sequencing analysis of OMI/HTRA2 shows previously reported pathogenic mutations in neurologically normal controls. Hum Mol Genet, Vol.17, No.13, pp. 1988-1993.

Sriram, S. R., Li, X., Ko, H. S., Chung, K. K., Wong, E., Lim, K. L., Dawson, V. L. \& Dawson, T. M. (2005). Familial-associated mutations differentially disrupt the solubility, localization, binding and ubiquitination properties of parkin. Hum Mol Genet, Vol.14, No.17, pp. 2571-2586.

Staropoli, J. F., McDermott, C., Martinat, C., Schulman, B., Demireva, E. \& Abeliovich, A. (2003). Parkin Is a Component of an SCF-like Ubiquitin Ligase Complex and Protects Postmitotic Neurons from Kainate Excitotoxicity. Neuron, Vol.37, No.5, pp. 735-749.

Tain, L. S., Mortiboys, H., Tao, R. N., Ziviani, E., Bandmann, O. \& Whitworth, A. J. (2009). Rapamycin activation of $4 \mathrm{E}-\mathrm{BP}$ prevents parkinsonian dopaminergic neuron loss. Nat Neurosci, Vol.12, No.9, pp. 1129-1135.

Tan, J. M., Wong, E. S., Dawson, V. L., Dawson, T. M. \& Lim, K. L. (2008a). Lysine 63-linked polyubiquitin potentially partners with p62 to promote the clearance of protein inclusions by autophagy. Autophagy, Vol.4, No.2, pp. 251-253.

Tan, J. M., Wong, E. S., Kirkpatrick, D. S., Pletnikova, O., Ko, H. S., Tay, S. P., Ho, M. W., Troncoso, J., Gygi, S. P., Lee, M. K., Dawson, V. L., Dawson, T. M. \& Lim, K. L. (2008b). Lysine 63-linked ubiquitination promotes the formation and autophagic clearance of protein inclusions associated with neurodegenerative diseases. Hum Mol Genet, Vol.17, No.3, pp. 431-439.

Tanaka, A., Cleland, M. M., Xu, S., Narendra, D. P., Suen, D. F., Karbowski, M. \& Youle, R. J. (2010). Proteasome and p97 mediate mitophagy and degradation of mitofusins induced by Parkin. J Cell Biol, Vol.191, No.7, pp. 1367-1380. 
Thomas, B. \& Beal, M. F. (2007). Parkinson's disease. Hum Mol Genet, Vol.16 Spec No. 2, pp. R183-194.

Tsai, Y. C., Fishman, P. S., Thakor, N. V. \& Oyler, G. A. (2003). Parkin facilitates the elimination of expanded polyglutamine proteins and leads to preservation of proteasome function. J Biol Chem, Vol.278, No.24, pp. 22044-22055.

Ulusoy, A., Bjorklund, T., Hermening, S. \& Kirik, D. (2008). In vivo gene delivery for development of mammalian models for Parkinson's disease. Exp Neurol, Vol.209, No.1, pp. 89-100.

Um, J. W., Min, D. S., Rhim, H., Kim, J., Paik, S. R. \& Chung, K. C. (2006). Parkin Ubiquitinates and Promotes the Degradation of RanBP2. J. Biol. Chem., Vol.281, No.6, pp. 3595-3603.

Van Laar, V. S., Arnold, B., Cassady, S. J., Chu, C. T., Burton, E. A. \& Berman, S. B. (2011). Bioenergetics of neurons inhibit the translocation response of Parkin following rapid mitochondrial depolarization. Hum Mol Genet, Vol.20, No.5, pp. 927-940.

Vives-Bauza, C., Zhou, C., Huang, Y., Cui, M., de Vries, R. L., Kim, J., May, J., Tocilescu, M. A., Liu, W., Ko, H. S., Magrane, J., Moore, D. J., Dawson, V. L., Grailhe, R., Dawson, T. M., Li, C., Tieu, K. \& Przedborski, S. (2010). PINK1-dependent recruitment of Parkin to mitochondria in mitophagy. Proc Natl Acad Sci U S A, Vol.107, No.1, pp. 378-383.

Walter, U., Klein, C., Hilker, R., Benecke, R., Pramstaller, P. P. \& Dressler, D. (2004). Brain parenchyma sonography detects preclinical parkinsonism. Mov Disord, Vol.19, No.12, pp. 1445-1449.

Wang, C., Ko, H. S., Thomas, B., Tsang, F., Chew, K. C., Tay, S. P., Ho, M. W., Lim, T. M., Soong, T. W., Pletnikova, O., Troncoso, J., Dawson, V. L., Dawson, T. M. \& Lim, K. L. (2005). Stress-induced alterations in parkin solubility promote parkin aggregation and compromise parkin's protective function. Hum Mol Genet, Vol.14, No.24, pp. 3885-3897.

Wang, C., Lu, R., Ouyang, X., Ho, M. W., Chia, W., Yu, F. \& Lim, K. L. (2007). Drosophila overexpressing parkin R275W mutant exhibits dopaminergic neuron degeneration and mitochondrial abnormalities. J Neurosci, Vol.27, No.32, pp. 8563-8570.

Wang, C., Tan, J. M., Ho, M. W., Zaiden, N., Wong, S. H., Chew, C. L., Eng, P. W., Lim, T. M., Dawson, T. M. \& Lim, K. L. (2005b). Alterations in the solubility and intracellular localization of parkin by several familial Parkinson's disease-linked point mutations. J Neurochem, Vol.93, No.2, pp. 422-431.

Wang, H., Song, P., Du, L., Tian, W., Yue, W., Liu, M., Li, D., Wang, B., Zhu, Y., Cao, C., Zhou, J. \& Chen, Q. (2011). Parkin ubiquitinates Drp1 for proteasome-dependent degradation: implication of dysregulated mitochondrial dynamics in Parkinson's disease. J Biol Chem.

West, A. B., Maraganore, D., Crook, J., Lesnick, T., Lockhart, P. J., Wilkes, K. M., Kapatos, G., Hardy, J. A. \& Farrer, M. J. (2002). Functional association of the parkin gene promoter with idiopathic Parkinson's disease. Hum Mol Genet, Vol.11, No.22, pp. 2787-2792.

Winklhofer, K. F. (2007). The parkin protein as a therapeutic target in Parkinson's disease. Expert Opin Ther Targets, Vol.11, No.12, pp. 1543-1552. 
Winklhofer, K. F., Henn, I. H., Kay-Jackson, P. C., Heller, U. \& Tatzelt, J. (2003). Inactivation of parkin by oxidative stress and C-terminal truncations: a protective role of molecular chaperones. J Biol Chem, Vol.278, No.47, pp. 47199-47208.

Wong, E. S., Tan, J. M., Wang, C., Zhang, Z., Tay, S. P., Zaiden, N., Ko, H. S., Dawson, V. L., Dawson, T. M. \& Lim, K. L. (2007). Relative sensitivity of parkin and other cysteinecontaining enzymes to stress-induced solubility alterations. J Biol Chem, Vol.282, No.16, pp. 12310-12318.

Yamada, M., Mizuno, Y. \& Mochizuki, H. (2005). Parkin gene therapy for alphasynucleinopathy: a rat model of Parkinson's disease. Hum Gene Ther, Vol.16, No.2, pp. 262-270.

Yamamoto, A., Friedlein, A., Imai, Y., Takahashi, R., Kahle, P. J. \& Haass, C. (2005). Parkin phosphorylation and modulation of its E3 ubiquitin ligase activity. J Biol Chem, Vol.280, No.5, pp. 3390-3399.

Yasuda, T., Miyachi, S., Kitagawa, R., Wada, K., Nihira, T., Ren, Y. R., Hirai, Y., Ageyama, N., Terao, K., Shimada, T., Takada, M., Mizuno, Y. \& Mochizuki, H. (2007). Neuronal specificity of alpha-synuclein toxicity and effect of Parkin co-expression in primates. Neuroscience, Vol.144, No.2, pp. 743-753.

Zhang, Y., Gao, J., Chung, K. K., Huang, H., Dawson, V. L. \& Dawson, T. M. (2000). Parkin functions as an E2-dependent ubiquitin- protein ligase and promotes the degradation of the synaptic vesicle-associated protein, CDCrel-1. Proc Natl Acad Sci U S A, Vol.97, No.24, pp. 13354-13359.

Zhong, L., Tan, Y., Zhou, A., Yu, Q. \& Zhou, J. (2005). RING finger ubiquitin-protein isopeptide ligase Nrdp1/FLRF regulates parkin stability and activity. J Biol Chem, Vol.280, No.10, pp. 9425-9430.

Ziviani, E., Tao, R. N. \& Whitworth, A. J. (2010). Drosophila parkin requires PINK1 for mitochondrial translocation and ubiquitinates mitofusin. Proc Natl Acad Sci U S A, Vol.107, No.11, pp. 5018-5023. 


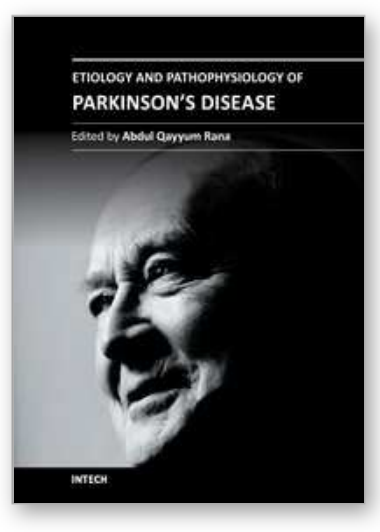

\author{
Etiology and Pathophysiology of Parkinson's Disease \\ Edited by Prof. Abdul Qayyum Rana
}

ISBN 978-953-307-462-7

Hard cover, 542 pages

Publisher InTech

Published online 12, October, 2011

Published in print edition October, 2011

This book about Parkinsonâ $€^{\mathrm{TM}} \mathrm{S}$ disease provides a detailed account of etiology and pathophysiology of Parkinsonâ€ ${ }^{\mathrm{TM}} \mathrm{s}$ disease, a complicated neurological condition. Environmental and genetic factors involved in the causation of Parkinsonâ€ ${ }^{\mathrm{TM}} \mathrm{S}$ disease have been discussed in detail. This book can be used by basic scientists as well as researchers. Neuroscience fellows and life science readers can also obtain sufficient information. Beside genetic factors, other pathophysiological aspects of Parkinsonâ $€^{\mathrm{TM}} \mathrm{s}$ disease have been discussed in detail. Up to date information about the changes in various neurotransmitters, inflammatory responses, oxidative pathways and biomarkers has been described at length. Each section has been written by one or more faculty members of well known academic institutions. Thus, this book brings forth both clinical and basic science aspects of Parkinsonâ€ ${ }^{\mathrm{TM}} \mathrm{S}$ disease.

\title{
How to reference
}

In order to correctly reference this scholarly work, feel free to copy and paste the following:

Shiam-Peng Tay, Grace G.Y. Lim, Calvin W.S. Yeo and Kah-Leong Lim (2011). Parkin and Parkinson's Disease, Etiology and Pathophysiology of Parkinson's Disease, Prof. Abdul Qayyum Rana (Ed.), ISBN: 978953-307-462-7, InTech, Available from: http://www.intechopen.com/books/etiology-and-pathophysiology-ofparkinson-s-disease/parkin-and-parkinson-s-disease

\section{INTECH}

open science | open minds

\author{
InTech Europe \\ University Campus STeP Ri \\ Slavka Krautzeka 83/A \\ 51000 Rijeka, Croatia \\ Phone: +385 (51) 770447 \\ Fax: +385 (51) 686166 \\ www.intechopen.com
}

\author{
InTech China \\ Unit 405, Office Block, Hotel Equatorial Shanghai \\ No.65, Yan An Road (West), Shanghai, 200040, China \\ 中国上海市延安西路65号上海国际贵都大饭店办公楼 405 单元 \\ Phone: +86-21-62489820 \\ Fax: $+86-21-62489821$
}


(C) 2011 The Author(s). Licensee IntechOpen. This is an open access article distributed under the terms of the Creative Commons Attribution 3.0 License, which permits unrestricted use, distribution, and reproduction in any medium, provided the original work is properly cited. 